\title{
The UK great bustard Otis tarda reintroduction trial: a 5-year progress report
}

\author{
Robert J. Burnside, I an Carter, Alasdair Dawes, David Waters \\ Leigh LoCK, PA U L Goriup and TAMás SzÉkely
}

\begin{abstract}
The great bustard Otis tarda became extinct in the UK during the 19th century due to a combination of factors, including hunting, egg collection and changes in agriculture. In 2003 a 10-year licence was granted to begin a trial to reintroduce the species back to the UK. Here we report on the first 5 years of the trial and assess the progress made towards establishing a founder population. From April 2004 to September 2009 a total of 102 great bustard chicks were imported from Russia and 86 released on Salisbury Plain. Monitoring showed that post-release survival was $18 \%$ in the first year following release, and that mortality of released bustards was mainly attributable to predation and collisions. Estimated adult survival was $74 \%$, although the sample size was small. All known surviving great bustards are faithful to the surroundings of the release site, returning throughout the year. A lek has been established where males have been observed displaying to females. The first nesting attempt was in 2007, and in 2009 two females aged 3 and 4 years successfully nested, fledging one chick each. Models incorporating the new demographic estimates suggest that at the end of the 10-year trial period the project can expect to have $8-26$ adults as a founder population.
\end{abstract}

Keywords Britain, great bustard, monitoring, Otis tarda, reintroduction, Russia, translocation, UK

\section{Introduction}

eintroduction has become an accepted intervention Rin conservation (Seddon et al., 2007; Armstrong \& Seddon, 2008) and has been widely used for various organisms, including birds and mammals. Because of the financial costs and low success rate rigorous assessment of feasibility is essential prior to implementation, as is appropriately long post-release monitoring to assess success

Robert J. Burnside (Corresponding author) and TAmÁs SzéKely University of Bath, Department of Biology and Biochemistry, Bath, BA2 7AY, UK. E-mail robertjohnburnside@hotmail.com

IAN CARTER Natural England, Peterborough, UK

Alasdair Dawes and David Waters Great Bustard Group, Winterbourne Gunner, Salisbury, UK

LEIGH LOCK Royal Society for the Protection of Birds, Sandy, UK

PAUL GORIUP Fieldfare International Ecological Development, Newbury, UK

Received 10 December 2010. Revision requested 1 February 2011.

Accepted 9 March 2011. First published online 24 November 2011.
(IUCN, 1998). However, when gaps in knowledge exist about the ecology of a species in an area from where it was extirpated, it is often difficult to determine the ability of that species to survive and persist once the original causes of extinction are removed. Consequently, trial reintroduction provides an opportunity to fill in the gaps in understanding and to assess the feasibility of a full-scale reintroduction project (Osborne, 2005).

Although the aim of a reintroduction is to establish a free-living, self-sustaining population, the progress of a reintroduction comprises a sequence of objectives, including the survival of released individuals, breeding by released individuals in the wild and then subsequent growth and persistence of the population (Seddon, 1999). Each of these stages must be assessed to identify the appropriate methodology and limitations (Seddon et al., 2007; Sutherland et al., 2010) and the importance of postrelease monitoring has been increasingly emphasized in assessing progress with reintroduction projects. In many cases, however, monitoring is found to be inadequate to assess success or failure appropriately (Fischer \& Lindenmayer, 2000; Armstrong \& Seddon, 2008). To assess the feasibility of reintroducing the great bustard Otis tarda to the UK it was recognized that comprehensive post-release monitoring would be needed to assess progress and to inform future strategic decisions.

The great bustard has a fragmented distribution extending across the middle latitudes from Morocco to China (Morales \& Martin, 2003). It is found on lowland grassland, steppe and arable land, and often displays a preference for low-intensity agriculture and crops over natural grasslands (Suarez-Seoane et al., 2002; Oparin et al., 2003; Morales et al., 2006; Magana et al., 2010). It is a polygamous ground-nesting bird and exhibits the largest sexual size dimorphism in body mass (females $3.5-7.2 \mathrm{~kg}$, males 7-13kg) of any bird species (Raihani et al., 2006; Székely et al., 2007; Alonso et al., 2009). The species was a common breeding bird across large parts of Europe and Asia during the 18th century (Gewalt, 1959) but underwent dramatic declines and local extinctions across its range during the 2oth century (Palacin \& Alonso, 2008). It is currently categorized as Vulnerable on the IUCN Red List (IUCN, 2010). The UK breeding population became extinct c. 1830 (Morales \& Martin, 2003) and, although the true cause of extinction is unknown (Collar, 1979), it was probably due to a combination of factors that included hunting, 
egg-collection and changes in agricultural practice (Osborne, 2005).

Because of the geographical isolation of the UK from existing Central and Southern European populations and the high site fidelity of great bustards (Martin et al., 2008), natural recolonization is unlikely to occur, even if conditions were suitable (Carter \& Newbery, 2004). An attempt was made to re-establish the species in the UK at Porton Down, Wiltshire, between 1970 and 1998, but this was unsuccessful because the captive-breeding approach failed to produce any chicks that survived to be released (Collar \& Goriup, 1980). Further captive-breeding attempts have so far been unsuccessful at producing enough chicks to make a reintroduction attempt viable (Martin, 1996). Therefore, translocation of captive-reared birds from a wild donor population is the only realistic option for a reintroduction project. A donor population was identified in Russia where eggs from nests that would otherwise be lost to cultivation could be rescued and birds hatched and reared in captivity.

Following a rigorous feasibility study based on the IUCN reintroduction guidelines (Osborne, 2002) it was concluded there would be no detrimental effects to the donor population and that the habitat and conditions on Salisbury Plain in Wiltshire could support this species. However, gaps exist in our knowledge of great bustard ecology and its ability to persist within the UK because of the long absence of the species. For the latter reasons a 10-year licence allowing the release of birds on a trial basis was issued in 2003 by the UK Government's Department for Environment, Food and Rural Affairs. In accordance with the IUCN Guidelines on Reintroductions, the licence application had a number of success indicators to help steer the project through the initial stages of establishing a founder population.

Here we report on progress with this project and evaluate it using the success indicators. We then model population growth using revised parameter estimates based on data from the reintroduced population and compare the outcomes with those predicted in the original feasibility study. This review covers the period from 30 April 2004 (when the first eggs were collected) to 14 September 2009 ( 5 years after the first release) by which time the first released birds were c. 60 months old.

\section{Study area}

The release site is on Salisbury Plain, the largest continuous area of calcareous grassland in north-west Europe, which is mainly contained within the county of Wiltshire. It has a low density of settlements and roads, and land-use is split between low-intensity grazing, agriculture and an extensive military training area $\left(380 \mathrm{~km}^{2}\right)$. The Salisbury Plain Site of Special Scientific Interest and Special Protection Area covers $197 \mathrm{~km}^{2}$ and is protected under domestic legislation and the EU Birds Directive (Osborne, 2005).

\section{Methods}

\section{Donor population and egg collection}

The donor population is in the Saratov Oblast, Russian Federation $\left(50^{\circ} 50^{\prime} \mathrm{N}, 46^{\circ} 12^{\prime} \mathrm{E}\right)$. Eggs are rescued from nests that would otherwise be lost to cultivation and transported via a portable incubation unit to a rearing station. The nesting period is prolonged, with a gap of 4 weeks between hatching of the first and last clutches. All eggs that fail to hatch are autopsied to check for infertility and any other problems. After hatching all chicks are individually marked with coloured leg rings. Chicks are reared in cohorts of similar age and fed using a dehumanising suit and puppet to decrease the risk of imprinting on humans. Juvenile birds aged 30-70 days are transported to the UK in animal crates in compliance with various national and international regulations, including CITES. Once in the UK the birds are kept in quarantine for 1 month during which time they are screened for avian influenza and paramyxovirus. Chicks are sexed by body size from the sexual size dimorphism that becomes apparent from c. 60 days.

\section{Release and monitoring}

Release into the wild takes place each year between September and October depending on the import date and weather conditions. The mean age at release is 100 days (range 58145), and birds are released into an open-topped fenced area (hereinafter, release pen) designed to exclude red foxes Vulpes vulpes and European badgers Meles meles. The release pen was 3.5 ha in 2004-2007, extended to 7 ha in 2008. The release pen is managed to contain a mosaic of arable crops, including oil seed rape, alfalfa and natural grassland. The release technique used during release has varied between years. In 2004 birds were kept in a netted enclosure within the release pen to allow them to become familiar with the environment prior to release but this method was discontinued because two males were injured in collision with the pen during attempts at flight (Osborne \& Fraser, 2005). In subsequent years all birds were released directly into the release pen. Limited predator control against Eurasian magpies Pica pica, carrion crows Corvus corone (potential nest predators) and red foxes is carried out in the immediate area around the release pen. However, predator control does not occur in the adjacent military areas and there is therefore the potential for rapid replacement of removed predators.

Released bustards were individually marked with numbered wing tags, colour-coded to identify release year. In addition, 55 individuals were fitted with backpack, neckcollar or tail-mounted radio transmitters (Biotrack TW-3, Biotrack Ltd, Wareham, UK), and 10 individuals were fitted with Argos/GPS enabled Platform Transmitter Terminals 
(PTT) (PTT-10o 105 gram LC4 ${ }^{\text {TM }}$ for males and PTT-10o 40 gram $\mathrm{LC}_{4}{ }^{\mathrm{TM}}$ for females; Microwave Telemetry Inc., Columbia, USA) that provided daily information on location.

The release site and its surroundings are intensively monitored by Great Bustard Group staff. In addition, with the aid of public relations work locally and nationally, opportunistic sightings away from the release site were reported by the public approximately once per week. Sightings of birds reported by the public were only used in our analyses when individual identity was verified. Mortalities were recorded via wing-tag, transmitter and carcass recoveries. Dates of mortality were estimated and were usually believed to be accurate to within a few days of death. Postmortems were carried out when possible, to establish cause of death, including screening for disease. Released individuals that were injured after release and taken back into captivity were recorded as dead for the purposes of analysis, with date of injury used as the date of mortality.

\section{Estimating reproductive and survival parameters}

Breeding attempts were assessed through intensive monitoring of the release area during the breeding period (March-June). Key signs indicative of breeding are displaying by males, signs of pecking on a female's head, and females exhibiting nesting behaviour (Morales \& Martin, 2003).

Because of the small sample sizes, data for males and females were pooled and only age-specific effects on survival were investigated. Pre-release survival is defined as the proportion of chicks surviving from import to release. Postrelease mortality was defined as the period from release to 12 months after release. Daily survivorship for the first year post-release was estimated using the Kaplan-Meier survival function. Individuals that were neither recovered nor resighted after 365 days were censored at their last resighting, whereas individuals that were known to survive for at least 365 days were censored at 365 days.

To estimate annual age-specific survival probabilities we used mark-resight data from all 86 released individuals and recoveries of dead birds. Date of marking was considered the day of the bustard's release, and intervals were set to 1 year from the date of first release on 15 September 2004 until 14 September 2009. Data used in the annual survival analysis were from resightings at the release site from September to December to meet the assumptions that resightings are obtained during a predefined sampling interval and within a defined sampling area. Dead recoveries from throughout the year were included in the dataset. Probabilities were estimated with MARK (White \& Burnham, 1999), using a Burnham Joint Live and Dead Encounters model that controls for study area effects (fidelity versus dispersal) that may influence detectability and probability of recovering dead individuals. The model was parameterized to explore differences between the year following release (juvenile $0-1$ year) and adulthood $\left(>_{1}\right.$ year). The candidate models were ranked using the corrected Akaike's Information Criterion (AICc) and the top performing model chosen. The logit link function was used for all models.

\section{Success criteria}

To assess short-term progress and identify limitations, success indicators (Table 1) were proposed in the original feasibility study. They were based on the best data available at the time from comparable great bustard rear-and-release projects in Hungary and Germany and from wild populations in Spain (Osborne, 2002).

\section{Population modelling}

We developed two demographic models to estimate the size of the founder population at time $t\left(N_{t}\right)$ at the end of the trial period, and used these models to explore various scenarios. Firstly, we used the deterministic model

$$
N_{t+1}=N_{t} \times S_{a}+I \times S_{\text {pre }} \times S_{\text {post }}
$$

to compare predicted population estimates before the trial (Osborne, 2002) with new estimates based on data presented here. In the original model (Model 1a), the number of eggs collected, fertility rate and hatch rate were used to estimate the number of birds required to be imported into the UK. These three parameters were replaced by the mean number of chicks imported (I), a product of the three components. Mortality was applied instantaneously to reflect the number of birds surviving by September each year, where $S_{a}$ is adult survival and $S_{\text {pre }}$ and $S_{\text {post }}$ are preand post-release survival respectively. We used the mean for each parameter estimate and did not incorporate measures of variation. Two scenarios were modelled: Model $1 \mathrm{~b}$, using the actual mean number of chicks translocated each year, and Model 1c, the desired number of chicks imported each year (40). These were compared with the pre-release survival model of Osborne (2002) and with the actual population growth.

Secondly, we incorporated demographic stochasticity in age-specific survival probabilities (Model 2). To account for uncertainty with survival estimates, 1,00o iterations of the population model were simulated. Each iteration was randomly assigned a survival probability for each age class from a survival probability beta distribution using the mean survival probability and its variance. Using three postrelease survival rates $(13,18,23 \%)$ and four importation rates $(10,20,30,40), 12$ scenarios were investigated. 
TABLE 1 Targets and success indicators for the first 5 years of the great bustard Otis tarda reintroduction, and estimates of demographic rates achieved. Success indicators were derived from release projects in Hungary and Germany and from wild birds in Spain (Osborne, 2002). Means are \pm SE (with $n$ in parentheses), with $95 \%$ confidence intervals (CI).

\begin{tabular}{|c|c|c|c|c|}
\hline Measure & Adequate & Excellent & $\begin{array}{l}\text { Reintroduction } \\
\text { project 2004-2009 }\end{array}$ & Target met? \\
\hline 1. Hatching success of artificially incubated eggs & $54 \%$ & $75 \%$ & $66.4 \%(232)$ & Yes \\
\hline $\begin{array}{l}\text { 2. Number of chicks imported from Russia } \\
\text { each year }\end{array}$ & 30 & 40 & $20.4 \pm 5.9(5)$ & No \\
\hline 3. Pre-release survival (males) & $53 \%$ & $75 \%$ & $88.0 \pm 6.3 \%(102)^{\star}$ & Yes \\
\hline 4. Pre-release survival (females) & $45 \%$ & $75 \%$ & & Yes \\
\hline 5. Post-release survival to end of year 1 (males) & $25 \%$ & $28 \%$ & $\begin{array}{l}18.2 \pm 4.6 \%(86)^{\star} \\
\text { CI } 10.8-28.9 \%\end{array}$ & No \\
\hline 6. Post-release survival to end of year 1 (females) & $38 \%$ & $42 \%$ & & No \\
\hline $\begin{array}{l}\text { 7. Post-release survival from year } 1 \text { per annum } \\
\text { (males) }\end{array}$ & $78 \%$ & $87 \%$ & $\begin{array}{l}74.6 \pm 10 \%(10)^{*} \\
\text { CI } 51.4-89.2 \%\end{array}$ & No \\
\hline $\begin{array}{l}\text { 8. Post-release survival from year } 1 \text { per annum } \\
\text { (females) }\end{array}$ & $83 \%$ & $92 \%$ & & No \\
\hline $\begin{array}{l}\text { 9. Year in which first evidence of breeding is } \\
\text { recorded }\end{array}$ & 5 & 4 & 4 & Yes \\
\hline
\end{tabular}

${ }^{\star}$ Male \& female data are pooled

Simulations were performed in $R v \cdot 2.12 .1$ (R Development Core Team, 2010). Neither modelling approach incorporated breeding for two reasons: our aim was to understand how many captive-reared individuals will be established through release only, and there are still few data available on reproductive parameters of released birds or survival of wild-reared bustards.

\section{Results}

\section{Number of released bustards}

The number of eggs rescued varied between years, influencing the number of imported and released bustards (Table 2). Ultimately, 102 chicks were imported into the UK (at an average of c. 20 birds per year). Mean pre-release survival from import to release (typically 1 month) was high at $88.0 \pm$ SE $6.3 \%)$. A total of 86 birds were released, of which 45 were females $(52.3 \%), 33$ were males $(38.3 \%)$, and 8 were unsexed (9.3\%; all birds of unknown sex died or were

TABLE 2 The number of eggs collected and hatched in Russia, and chicks transported and released in the UK great bustard reintroduction trial from 2004 to 2008 .

\begin{tabular}{lllllll}
\hline & 2004 & 2005 & 2006 & 2007 & 2008 & Total \\
\hline $\begin{array}{c}\text { Number of eggs } \\
\text { collected }\end{array}$ & 61 & 61 & 25 & 32 & 53 & 232 \\
$\begin{array}{c}\text { Number of eggs } \\
\text { hatched }\end{array}$ & 48 & 47 & 14 & 6 & 39 & 154 \\
$\begin{array}{c}\text { Number of chicks } \\
\text { transported to UK }\end{array}$ & 28 & 38 & 9 & 6 & 21 & 102 \\
$\begin{array}{c}\text { Number of chicks } \\
\text { released in the UK }\end{array}$ & 22 & 32 & 9 & 6 & 17 & 86 \\
\hline
\end{tabular}

not resighted before any obvious sexual dimorphism was apparent). Of the birds released, $69.7 \%$ had known fates (7 alive, 46 dead and 7 disabled) and 30.3\% had unknown fates by September 2009 .

\section{Survival and causes of mortality}

Mortality was high during the first 150 days after release (Fig. 1a) with only $26.9 \%$ (95\% confidence interval, CI, 17.741.1) of individuals surviving through this period. Subsequently survival from 150 to 365 days remained constant, with no deaths reported, although two individuals were not seen after 305 days. There was no significant difference between the survival rate of males and females (Cox regression: $\mathrm{n}=78, z=0.224, \mathrm{P}=0.82$; Fig. $1 \mathrm{~b}$ ). Annual survival from the top-ranked model in the mark-recapture analysis (Table 3) for 1 year after release was estimated to be 18.2\% (95\% CI 10.8-28.9). Annual survival for birds $>1$ year was estimated to be $74.6 \%$ (95\% CI 51.4-89.2). There was a high probability of resighting newly released individuals at the release site $(82.2 \%, 95 \%$ CI 50.2-95.4), and all surviving individuals older than 1 year returned to the release site. Using the joint live and dead encounters the estimated probability of recovering dead individuals was 67.4\% (95\% CI 55.7-77.2).

Pre-release survival during transportation and quarantine was high but some individuals were injured as a result of collisions with the quarantine pens during attempts to fly. Post-release, there was no evidence in recovered carcasses of starvation or malnourishment. In many cases it was difficult to determine the cause of death because carcasses had been scavenged. There were two isolated incidences of infection in 2005, with one instance of 


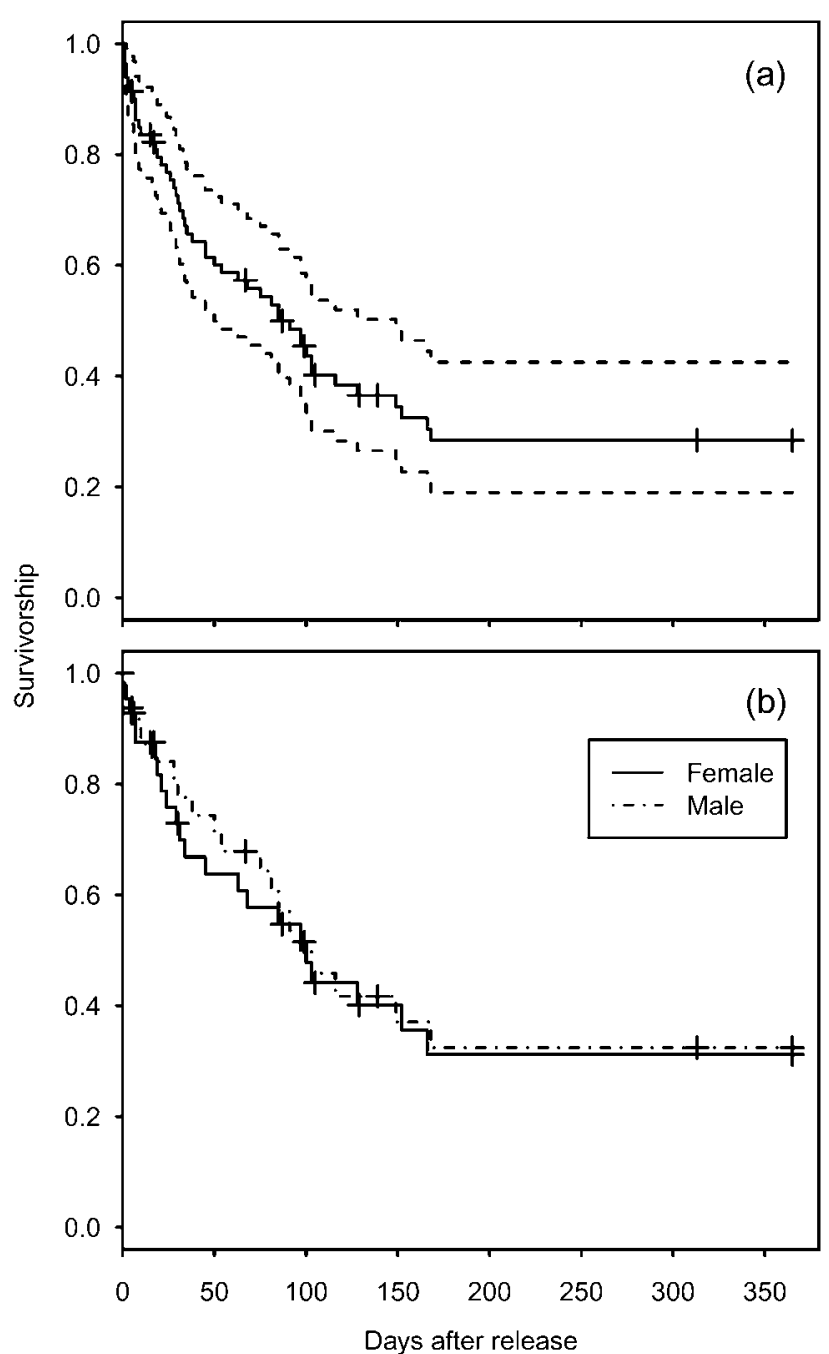

FIG. 1 Estimated survival of reintroduced great bustards Otis tarda. (a) All 86 individuals released between September 2004 and September 2009 (solid line), and 95\% confidence intervals (dashed lines). (b) Survivorship separated by sex for 45 females and 33 males. Cross-hair ticks indicate censored individuals that were not recovered or resighted after the indicated date during the 365 days.

yersiniosis, probably from a wild rodent, and one unidentified infection. Predation accounted for death in most cases where the cause of death could be confirmed. Red foxes are thought to be responsible for the majority of predation, although the European badger may also have been responsible. Collision, with power-lines and agricultural fences, was the second most important cause of mortality identified (Fig. 2).

\section{Breeding}

The first great bustard clutch was laid in 2007 by a 2-year old female. She also nested in 2008, although, clutches in both years were infertile. In 2009 two females nested (a 3-year old female and the 4-year old female that had nested the previous 2 years) with one clutch hatching one chick and the other hatching two chicks. Both females successfully fledged one chick.

\section{Success indicators}

Four of the nine indicators were met (Table 1). In addition, three of the targets were potentially met given the large range of uncertainty in parameter estimates because of small sample sizes. Three targets were below adequate: the average number of birds imported has been half of the licence import quota of 40 birds each year, post-release survival was lower than expected, and adult survival failed to meet the adequate target for either sex although the confidence limits are large.

\section{Population modelling}

Based on the parameters in Table 4, Model 1a estimated 108 individuals after 10 years using 400 imported bustards (Fig. 3). However, it was apparent after the first year of release that this would be an overly optimistic prediction (Osborne \& Fraser, 2005). Model $1 \mathrm{~b}$ predicts 12 individuals will be recruited into the breeding population from 200 imported birds during the trial period (Fig. 3), and is consistent with actual population growth (Fig. 3). Importing the originally estimated 40 birds per year would double the predicted founder population to 24 individuals (Model 1c).

Model 2 shows that there is uncertainty in how the population may develop because of large variation in the estimates of post-release and adult survival (Fig. 4). At the current rates of 20 birds imported per year and $18 \%$ postrelease survival, the founder population has a $95 \%$ chance of reaching 8-26 individuals at an equal sex ratio. Improving the post-release survival rate to $23 \%$ and importing 40 chicks each year resulted in a predicted founding population of 32-56 individuals. The latter predictions are higher than estimated in Model 1. However, currently the population growth is at the lower end of the outcomes predicted by these models. Both models suggest that if importation rates are between 1 and 20 birds then the founder population after 10 years would be between 1 and 11 individuals.

\section{Discussion}

The first 5 years of the reintroduction trial have demonstrated that great bustards can be hatched in captivity from wild collected eggs and that juveniles can be translocated from Russia and successfully released into the wild in the UK. Furthermore, it has shown that released birds can survive in the wild over long periods and are generally faithful to the release area. In recent years, released birds have reached maturity and have reproduced successfully on Salisbury Plain. 
TABLE 3 Summary of model selection from annual survival of great bustards in the UK reintroduction trial as calculated from a Burnham Live and Dead Encounters model. Age specific mortality $\left(S_{i}\right)$, probability of resighting a live individual ( $\left.p_{i}\right)$, probability of recovering a dead individual $\left(\mathrm{r}_{\mathrm{i}}\right)$ and probability an individual will remain in the sampling area $\left(\mathrm{F}_{\mathrm{i}}\right)$ were considered. Age structure (i) was defined as 1, where the estimate is constant across age groups and, 2 for two age groups split into first year and adult (2-5 years). All models were fitted with a logit link function and ranked according to the corrected Akaike Information Criteria (AICc).

\begin{tabular}{lllllll}
\hline Model & AICc & $\Delta$ AICc & AICc weights & $\begin{array}{l}\text { Model } \\
\text { likelihood }\end{array}$ & $\begin{array}{l}\text { No. of } \\
\text { parameters }\end{array}$ \\
\hline $\mathrm{S}_{2} \mathrm{p}_{2} \mathrm{r}_{1} \mathrm{~F}_{1}$ & 209.89 & 0 & 0.475 & 1 & 4 & Deviance \\
$\mathrm{S}_{2} \mathrm{p}_{2} \mathrm{r}_{2} \mathrm{~F}_{2}$ & 211.09 & 1.20 & 0.260 & 0.54 & 5 & 34.79 \\
$\mathrm{~S}_{2} \mathrm{p}_{2} \mathrm{r}_{1} \mathrm{~F}_{2}$ & 211.78 & 1.89 & 0.184 & 0.38 & 5 & 33.80 \\
$\mathrm{~S}_{2} \mathrm{p}_{1} \mathrm{r}_{2} \mathrm{~F}_{2}$ & 213.73 & 3.83 & 0.069 & 0.14 & 5 & 34.49 \\
$\mathrm{~S}_{2} \mathrm{p}_{1} \mathrm{r}_{1} \mathrm{~F}_{1}$ & 224.84 & 14.9 & 0.00027 & 0.0006 & 3 & \\
$\mathrm{~S}_{1} \mathrm{p}_{2} \mathrm{r}_{1} \mathrm{~F}_{1}$ & 227.89 & 18.00 & 0.00006 & 0.0001 & 3 & 53.03 \\
\hline
\end{tabular}

The progress of the project has been assessed through intensive monitoring of individuals that were systematically marked from the beginning of the trial. Although postrelease mortality has been high, individuals from every year of release have survived to adulthood, confirming that the habitat around Salisbury Plain can support individual great bustards. The reintroduced great bustards have not exhibited the long distance migratory behaviour known from the donor population in Russia (Watzke, 2007b), with the exception of three individuals that flew to France in 2005 shortly after their release. Ultimately two of these individuals died and one has remained unaccounted for. All known surviving bustards have returned to the release site throughout the year but they are also known, based on reports of wing-tagged birds and data from birds fitted with satellite tags, to have explored widely in south-west England (R.J. Burnside et al., unpubl. data).

The presence of conspecifics has influence on the natal dispersal of great bustards in wild populations as well as the use of lek sites by males, with juvenile birds using the presence of other great bustards as indicators of habitat quality (Alonso et al., 2004; Martin et al., 2008). However, even in the absence of these cues, males in the UK displayed and returned to the release site to lek. This has management implications in relation to the potential benefits of establishing new release sites and leks in south-west England to start creating a meta-population structure.

Although released females have been able to locate suitable nesting habitat and have successfully reared chicks, suggesting that arthropod abundance/biomass is sufficient in the breeding area, the number of breeding attempts is too small to be able to draw conclusions about nesting success or productivity rates. The level of breeding success was expected to be low at the beginning of the project since first-time breeders tend to have a lower success rate than mature and experienced bustards (Ena et al., 1987; Morales et al., 2002; Watzke, 2007a; Martinez, 2008). As the population grows and the age structure develops we expect breeding success to improve as more females will be available to breed and older females have a higher probability of successfully rearing chicks (Morales et al., 2002). The social stimulation created by recruitment of breeding individuals will reduce potential Allee effects associated with small populations.

The low numbers of birds released and the low postrelease survival rates have clearly limited the success of the reintroduction trial. In extant populations juvenile survival is estimated to be $29.9 \%$ in the first year (Martin et al., 2007). Our results are comparable although the high mortality phase takes place post-release, when birds are 3-8 months old, rather than during the first 3 months as recorded by Martin et al. (2007). Low post-release survival is common in reintroductions across various taxa (Teixeira et al., 2007). This is potentially the result of captive-reared

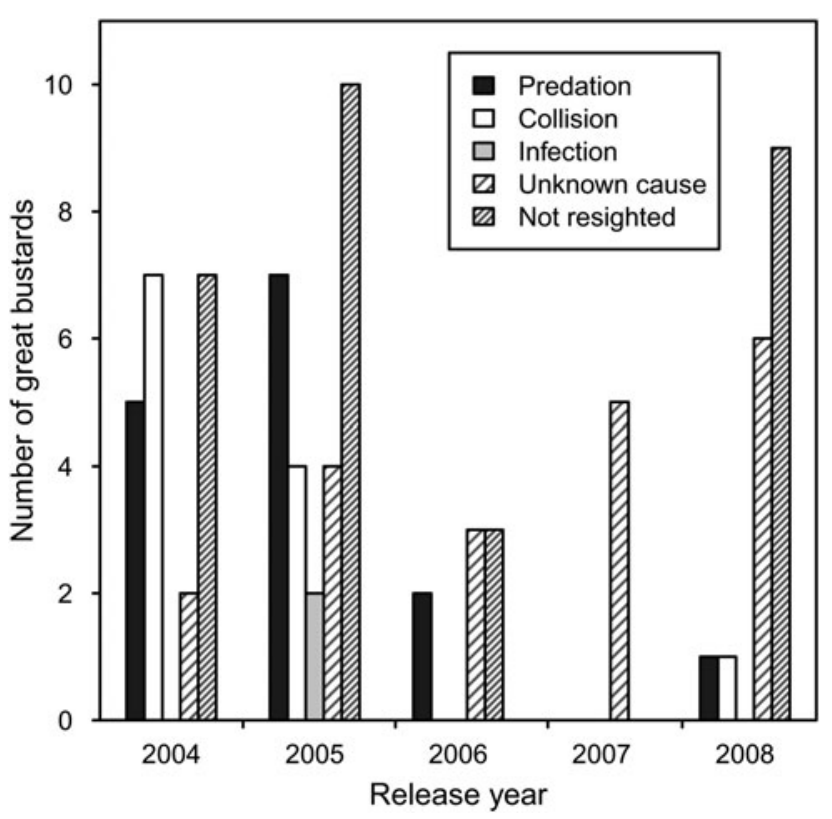

FIG. 2 Fates of captive-reared great bustard juveniles reintroduced to the UK between 2004 and 2008. 
TABLE 4 Model parameters for the reintroduced great bustard population.

\begin{tabular}{lll}
\hline & $\begin{array}{l}\text { Parameters } \\
\text { of model } \\
\text { (Osborne, }\end{array}$ & $\begin{array}{l}\text { Achieved } \\
\text { parameters } \\
(2004-2009)\end{array}$ \\
Parameter & $2002)$ & $46.4^{*}$ \\
\hline Eggs collected each year & 75 & $84.3 \%^{*}$ \\
Fertile eggs & $75 \%$ & $66 \%^{*}$ \\
$\begin{array}{l}\text { Eggs hatched } \\
\text { Number of chicks imported }\end{array}$ & $72 \%$ & 20.4 \\
$\begin{array}{l}\text { Conservative survival } \\
\quad \text { until release (male) }\end{array}$ & $53 \%$ & $88 \%$ \\
$\begin{array}{l}\text { Conservative survival } \\
\text { until release (female) }\end{array}$ & $43 \%$ & $88 \%$ \\
$\begin{array}{l}\text { Post-release survival to end } \\
\text { of year 1 (females) }\end{array}$ & $88 \%$ & $18.2 \%$ \\
Post-release survival to end & $88 \%$ & $18.2 \%$ \\
$\quad$ of year 1 (males) & & \\
$\begin{array}{l}\text { Survival }>1 \text {-year old female } \\
\text { Survival }>1 \text {-year old male }\end{array}$ & $87 \%$ & $74.6 \%$ \\
\hline
\end{tabular}

${ }^{\star}$ Parameters were not used in the model

individuals lacking the appropriate behavioural responses to survive in the wild (Griffin \& Blumstein, 2000).

Maternally learned skills are likely to be important to juvenile great bustards because in the wild they stay with the mother for over 6 months (Martin et al., 2008). A number of studies have shown that wild-reared individuals

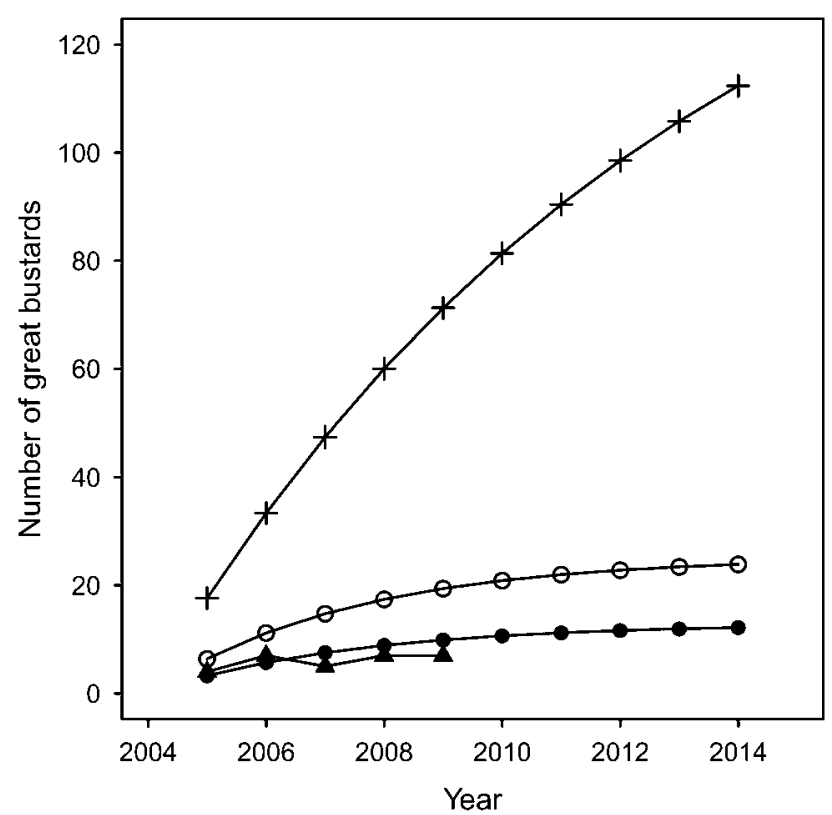

FIG. 3 Predicted population size of UK reintroduced population of great bustard through rear-and-release and assuming there is no breeding occurring. Model 1a (+): projected growth before the start of the project (Osborne, 2002); Model $1 \mathrm{~b}(\bullet)$ : revised model importing 20 chicks per year; Model $1 \mathrm{c}(\circ)$ : revised model importing 40 chicks per year; $(\mathbf{\Lambda})$ : actual population growth from 2004. have higher survival rates than captive-reared conspecifics (Griffith et al., 1989; Wolf et al., 1996). The Brandenburg (Germany) great bustard release project has experienced similar and variable post-release survival, estimated to be $15-40 \%$ of released individuals from release to the following spring (Eisenberg, 2008). Fox predation had been the main cause of mortality in the latter project, which was mitigated to some extent by the use of predator-free fenced areas. Recently however, white-tailed eagles Haliaeetus albicilla are reported to have caused substantial mortality in juvenile birds (Eisenberg, 2008). Houbara bustard Chlamydotis undulata release projects have had similar difficulties with fox predation (Combreau \& Smith, 1998).

Captive-reared animals often lack essential skills such as predator recognition (Griffin \& Blumstein, 2000). Predator-awareness training with a live predator improves post-release survival in houbara bustards (van Heezik et al., 1999), although there are few empirical studies that confirm its effectiveness in other species of birds. In great bustards the effort to elicit the correct flight response to a predator can lead to injuries when the birds are in confinement (D. Waters, pers. comm.). Collisions have also been an important cause of mortality post-release, which may be due in part to behavioural naivety or perhaps to a reduction in feather quality due to time spent in captivity, and the handling necessary during transport and veterinary checks. However, collisions are known to be an important cause of mortality in several bustard species including the great bustard, Kori bustard Ardeotis kori, Denham's bustard Neotis denhami and little bustard Tetrax tetrax (Janss \& Ferrer, 2000; Martin \& Shaw, 2010; Shaw et al., 2010; Silva et al., 2010).

In the wild, adult survival is thought to be high, estimated at $92 \%$ in Iberian populations (Martin et al., 2007). The reintroduced UK population has a comparable high rate although the estimate is based on only a small sample. Estimates and the resulting reliability of model predictions should improve in future when more data will become available. On current estimates we predict that the growth of the founder population through continued supplementation will be slower than originally envisaged (Osborne, 2002). This is primarily due to the small numbers recruiting into the population, which is a result of low import numbers and post-release survival. Assuming these parameters do not improve, a longer period of time will be required to establish a founder population sufficiently large to have a high chance of persisting in the wild in the long term. Whilst the population is still small it remains prone to stochastic events such as a period of high mortality due to extreme weather, and a reduction in the potential benefits of social stimuli from conspecifics.

Small population size also increases the challenge of assessing the project quantitatively rather than qualitatively, making it harder to plan for the future (Seddon et al., 


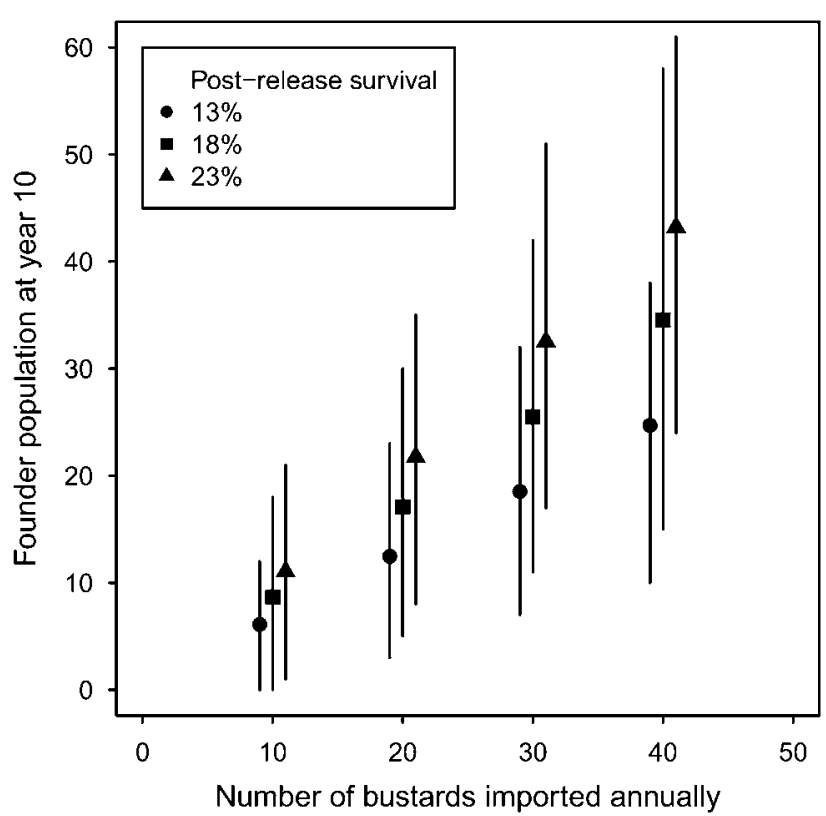

FIG. 4 Estimated founder population sizes for great bustards reintroduced to the UK at the end of the 10-year trial period using 12 scenarios of post-release survival and number of birds imported to the UK (see Methods for details, Model 2). Lines are two standard deviations above and below the estimated mean after 1,000 runs and represent the $95 \%$ probability of attaining a population of this size.

2007; Armstrong \& Seddon, 2008). There is limited value in measuring progress of a reintroduced population using data from existing wild populations, as there will be considerable variation in factors such as anthropogenic disturbance, infrastructure, predator types, climate, attitudes to conservation, and availability/access to other subpopulations in different areas. The values of demographic parameters required to ensure a self-sustaining population are thus likely to be different in southern England from those of other populations. For this reason modelling is an appropriate approach to investigate the rates of recruitment needed for sustainable growth and to set success indicators accordingly (Seddon, 1999; Seddon et al., 2007; Armstrong \& Seddon, 2008). The reliability of these models should improve as more data become available from monitoring of the expanding population.

Reintroduction projects involving red kite Milvus milvus, white-tailed eagle and, to a lesser extent, osprey Pandion haliaetus in Britain have already achieved considerable success (Green et al., 1996; Evans et al., 1999). However, success rates tend to be higher in birds of prey than in other birds (Cade, 2000). The great bustard is one of a number of bird reintroductions that are currently in progress in Britain, with other projects involving the corn crake Crex crex, cirl bunting Emberiza cirlus and common crane Grus grus. The results of these projects may have considerable influence on the extent to which this sometimes contentious approach to conservation is utilized in future.
Although this experimental reintroduction has shown some encouraging signs of success it is still at an early stage, and further work will be required to establish a selfsustaining population. The numbers of birds released annually are, on average, about half of that planned. While this may not undermine the project in the long term, it does increase the likely time-scale for success. Accordingly, we recommend that priority should be given to increasing the number of birds released each year.

Continued supplementation will provide a buffer against stochastic effects that could result in the population being reduced to dangerously low levels or going extinct. Current rates of post-release survival are limiting the growth of the population. Experimentally investigating ways to improve survival may offset low import numbers and will be of potential benefit to global bustard conservation as a whole. Accumulating improved demographic data about the newly established population for modelling purposes is particularly important. Long-term post-release monitoring will be essential to underpin a strategy for taking this reintroduction project forward, through improving our understanding of habitat use, breeding productivity, survival of wildreared chicks and rates of population growth.

\section{Acknowledgements}

We gratefully acknowledge Dr Anatoli Khrustov, Director of the A.N. Severtsov Institute of Evolution and Ecological Problems (Saratov Branch), Russian National Academy of Science for his critical role in making the reintroduction possible. Tatiana Pereverzina is responsible for the captive rearing of chicks in Saratov. Veterinary consultation is provided by John Chitty and virology is done by Dr Ruth Manvell. The Great Bustard Group is a registered charity that runs the project day-to-day and has invaluable help from many volunteers. The Great Bustard Consultative Committee provided a forum for sharing ideas, with special thanks to James Ferguson-Lees, Tracé Williams (RSPB) and Defence Estates for their support. International collaboration with other great bustard range states has been invaluable, drawing on expertise in harness fitting from Dr Juan Carlos Alonso (Museo Nacional de Ciencias Naturales), and experiences of rearing and releasing great bustards from Körös-Maros National Park (Hungary) and Torsten Langgemach from the Brandenburg Project (Germany). Monitoring during the first 1.5 years was carried out by Dr Patrick Osborne and Anna Fraser from the University of Southampton. We thank the two anonymous reviewers for their comments.

\section{References}

Alonso, J.C., Magana, M., Alonso, J.A., Palacin, C., Martin, C.A. \& MARTin, B. (2009) The most extreme sexual size 
dimorphism among birds: allometry, selection, and early juvenile development in the great bustard (Otis tarda). Auk, 126, 657-665.

Alonso, J.C., Martin, C.A., Alonso, J.A., Palacin, C., Magana, M. \& Lane, S.J. (2004) Distribution dynamics of a great bustard metapopulation throughout a decade: influence of conspecific attraction and recruitment. Biodiversity and Conservation, 13, 1659-1674.

Armstrong, D.P. \& Seddon, P.J. (2008) Directions in reintroduction biology. Trends in Ecology \& Evolution, 23, 20-25.

CADE, T.J. (2000) Progress in translocation of diurnal raptors. In Raptors at Risk (eds R.D. Chancellor \& B.U. Meyburg), pp. 343372. WWGBP/Hancock House, Berlin, Germany.

Carter, I. \& Newbery, P. (2004) Reintroduction as a tool for population recovery of farmland birds. Ibis, 146, 221-229.

Collar, N.J. (1979) The great bustard in Britain and Portugal. In Symposium Papers on the Great Bustard and the Houbara Bustard. CIC and Game Conservancy, Fordingbridge, UK.

Collar, N.J. \& Goriup, P.D. (1980) Problems and progress in the captive breeding of great bustards Otis tarda in quasi-natural conditions. Avicultural Magazine, 86, 131-140.

Combreau, O. \& Smith, T.R. (1998) Release techniques and predation in the introduction of houbara bustards in Saudi Arabia. Biological Conservation, 84, 147-155.

Eisenberg, A. (2008) Post-release monitoring in Germany. Bustard Studies, 7, 19-26.

Ena, V., Martinez, A. \& Thomas, D.H. (1987) Breeding success of the great bustard Otis tarda in Zamora Province, Spain, in 1984. Ibis, 129, 364-370.

Evans, I. M., Summers, R. W., O’Toole, L., Orr-Ewing, D. C., Evans, R., Snell, N. \& Smith, J. (1999) Evaluating the success of translocating red kites Milvus milvus to the UK. Bird Study, 46, 129-144.

Fischer, J. \& Lindenmayer, D.B. (2000) An assessment of the published results of animal relocations. Biological Conservation, 96, 1-11.

Gewalt, W. (1959) Die Großtrappe. Die Neue Brehm-Bücherei, Wittenberg-Lutherstadt, Germany.

Green, R.E., Pienkowski, M.W. \& Love, J.A. (1996) Long-term viability of the reintroduced population of the white-tailed eagle Haliaeetus albicilla in Scotland. Journal of Applied Ecology, 33, 357-368.

Griffin, A.S. \& Blumstein, D.T. (2000) Training captive-bred or translocated animals to avoid predators. Conservation Biology, 14, $1317-1326$

Griffith, B., Scott, J.M., Carpenter, J.W. \& Reed, C. (1989) Translocation as a species conservation tool: status and strategy. Science, 245, 477-480.

IUCN (1998) Guidelines for Re-introductions. IUCN/SSC Reintroduction Specialist Group, Gland, Switzerland.

IUCN (2010) IUCN Red List of Threatened Species. IUCN, Gland, Switzerland. Http://www.iucnredlist.org [accessed 25 July 2010].

Janss, G.F.E. \& Ferrer, M. (2000) Common crane and great bustard collision with power lines: collision rate and risk exposure. Wildlife Society Bulletin, 28, 675-680.

Magana, M., Alonso, J.C., Martin, C.A., Bautista, L.M. \& Martin, B. (2010) Nest-site selection by great bustards Otis tarda suggests a trade-off between concealment and visibility. Ibis, 152, $77-89$.

MARTIN, E. (1996) Evaluation of captive breeding as a method to conserve threatened great bustard (Otis tarda) populations. In Conservación de las Aves Esteparias y su Habitat (eds J.F. Gutierrez \& J. Sanz-Zuasti), pp. 131-136. Junta de Castilla y León, Valladolid, Spain.
Martin, C.A., Alonso, J.C., Alonso, J.A., Palacin, C., Magana, M. \& Martin, B. (2007) Sex-biased juvenile survival in a bird with extreme size dimorphism, the great bustard Otis tarda. Journal of Avian Biology, 38, 335-346.

Martin, C.A., Alonso, J.C., Alonso, J.A., Palacin, C., Magana, M. \& Martin, B. (2008) Natal dispersal in great bustards: the effect of sex, local population size and spatial isolation. Journal of Animal Ecology, 77, 326-334.

MARTin, G.R. \& Shaw, J.M. (2010) Bird collisions with power lines: failing to see the way ahead? Biological Conservation, 143, 2695-2702.

Martinez, C. (2008) Distribution, density and productivity of great bustards Otis tarda in north western Spain: a regional approach. Journal of Ornithology, 149, 507-514.

Morales, M.B., Alonso, J.C. \& Alonso, J. (2002) Annual productivity and individual female reproductive success in a great bustard Otis tarda population. Ibis, 144, 293-300.

Morales, M.B. \& Martin, C. (2003) Otis tarda great bustard. In Birds of the Western Palearctic Update (eds S. Cramp \& K.E.L. Simmons), pp. 217-232. Oxford University Press, Oxford, UK.

Morales, M.B., Suarez, F. \& de la Morena, E.L.G. (2006) Response of steppe birds to various levels of farming intensity and of modification of the agricultural landscape: a comparative analysis of their effects on population density and habitat selection in the little and great bustards (Tetrax tetrax and Otis tarda). La terre et la vie: Revue d'écologie, 61, 261-270.

Oparin, M.L., Kondratenkov, I.A. \& Oparina, O.S. (2003) Abundance of the Transvolga population of great bustard (Otis tarda L.). Biology Bulletin, 30, 562-569.

Osborne, P.E. (2002) Application to the Department for Environment, Food and Rural Affairs for a Licence to Re-introduce Great Bustards Otis tarda to Britain. Unpublished report, Great Bustard Group, Salisbury, UK.

Osborne, P.E. (2005) Key issues in assessing the feasibility of reintroducing the great bustard Otis tarda to Britain. Oryx, 39, 22-29.

Osborne, P.E. \& Fraser, A.M.P. (2005) Reintroducing great bustards (Otis tarda) to Britain: context, challenges and first results. Aquila, 112, 175-182.

Palacin, C. \& Alonso, J.C. (2008) An updated estimate of the world status and population trends of the great bustard Otis tarda. Ardeola, 55, 13-25.

Raihani, G., Székely, T., Serrano-Meneses, M.A., Pitra, C. \& Goriup, P. (2006) The influence of sexual selection and male agility on sexual size dimorphism in bustards (Otididae). Animal Behaviour, 71, 833-838.

R Development Core Team (2010) R: A Language and Environment for Statistical Computing. R Foundation for Statistical Computing, Vienna, Austria. Http://www.R-project.org [accessed 24 May 2011].

Seddon, P.J. (1999) Persistence without intervention: assessing success in wildlife reintroductions. Trends in Ecology \& Evolution, 14, 503-503.

Seddon, P.J., Armstrong, D.P. \& Maloney, R.F. (2007) Developing the science of reintroduction biology. Conservation Biology, 21, 303-312.

Shaw, J.M., Jenkins, A.R., Ryan, P.G. \& Smallie, J.J. (2010) A preliminary survey of avian mortality on power lines in the Overberg, South Africa. Ostrich, 81, 109-113.

Silva, J.P., Santos, M., Queiros, L., Leitao, D., Moreira, F., Pinto, M. et al. (2010) Estimating the influence of overhead transmission power lines and landscape context on the density of little bustard Tetrax tetrax breeding populations. Ecological Modelling, 221, 1954-1963.

Suarez-Seone, S., Osborne, P.E. \& Alonso, J.C. (2002) Largescale habitat selection by agricultural steppe birds in Spain: 
identifying species-habitat responses using generalized additive models. Journal of Applied Ecology, 39, 755-771.

Sutherland, W.J., Armstrong, D., Butchart Stuart, H.M., Earnhardt, J.M., Ewen, J., Jamieson, I. et al. (2010) Standards for documenting and monitoring bird reintroduction projects. Conservation Letters, 3, 229-235.

Székely, T., Lislevand, T. \& Figuerola, J. (2007) Sexual size dimorphism in birds. In Sex, Size and Gender Roles: Evolutionary Studies of Sexual Size Dimorphism (eds D. Fairbairn, W. Blanckenhorn \& T. Székely), pp. 27-37. Oxford University Press, Oxford, UK.

Teixeira, C.P., de Azevedo, C.S. \& Mendl, M. (2007) Revisiting translocation and reintroduction programmes: the importance of considering stress. Animal Behaviour, 73, 1-14.

van Heezik, Y., Seddon, P.J. \& Maloney, R.F. (1999) Helping reintroduced houbara bustards avoid predation: effective antipredator training and the predictive value of pre-release behaviour. Animal Conservation, 2, 155-163.

W AтZKe, H. (2007a) Reproduction and causes of mortality in the breeding area of the great bustard in the Saratov region of Russia. Bustard Studies, 6, 53-64.

W AтZKe, H. (2007b) Results from satellite telemetry of great bustards in the Saratov region of Russia. Bustard Studies, 6, 83-98.
White, G.C. \& Burnham, K.P. (1999) Program MARK: survival estimation from populations of marked animals. Bird Study, 46, 120-139.

Wolf, C.M., Brad, G., Christine, R. \& Stanley, A.T. (1996) Avian and mammalian translocations: update and reanalysis of 1987 survey data. Conservation Biology, 10, 1142-1154.

\section{Biographical sketches}

ROBERT JOHN BURNSIDE is interested in the use of reintroduction as a conservation tool and the design of monitoring techniques for assessing success. IAN CARTER has worked as an ornithologist with Natural England (and predecessors) for over 20 years and has a particular interest in bird reintroductions. Alasdair Dawes has worked in conservation for over 10 years, with a particular interest in birds. DA VID W A T ERs is the Director of the Great Bustard Group, an organization he founded in 1998. LEIGH LOCK works for the RSPB on various species recovery projects across the UK. PAUL GORIUP has worked with great bustards for 30 years. TAMÁs SzÉKELY is interested in biodiversity conservation and specializes in avian breeding systems. 